\section{Differential Nitrogen and Phosphorus Recovery by Five Aquatic Garden Species in Laboratory-scale Subsurface-constructed Wetlands}

\author{
Robert F. Polomski ${ }^{1,6}$, Douglas G. Bielenberg ${ }^{3}$, and Ted Whitwell ${ }^{5}$ \\ Department of Horticulture, Clemson University, 254 Poole Agricultural \\ Center, Clemson, SC 29634-0319
}

\author{
Milton D. Taylor ${ }^{2}$ \\ InsectiGen, Inc., 425 River Road, Athens, GA 30602 \\ William C. Bridges ${ }^{4}$ \\ Department of Applied Economics and Statistics, Clemson University, \\ Clemson, SC 29634-0313
}

Stephen J. Klaine ${ }^{4}$

Department of Biological Sciences, Clemson Institute of Environmental Toxicology, P.O. Box 709, Clemson University, Pendleton, SC 29670

Additional index words. water quality, Oenanthe javanica 'Flamingo', Phyla lanceolata, Rhyncospora colorata, Thalia geniculata f. rheumoides, Typha minima

\begin{abstract}
Intensive production of container-grown nursery and greenhouse crops in soilless substrate may result in significant leaching of nutrients and pesticides. The resulting runoff can escape from production areas and negatively impact surface and ground water. Constructed wetlands (CWs) have been shown to be a simple, lowtechnology method for treating agricultural, industrial, and municipal wastewater. We investigated the nitrogen $(N)$ and phosphorus $(P)$ removal potential by a vegetated, laboratory-scale subsurface flow (SSF) CW system. Over an 8-week period, five commercially available aquatic garden plants received a range of $N$ and $P\left(0.39\right.$ to $36.81 \mathrm{mg} \cdot \mathrm{L}^{-1} \mathrm{~N}$ and 0.07 to $6.77 \mathrm{mg} \cdot \mathrm{L}^{-1} \mathrm{P}$ ) that spanned the rates detected in nursery runoff. Whole plant dry weight was positively correlated with $N$ and $P$ supplied. Highest $N$ and $P$ recovery rates were exhibited by Thalia geniculata f. rheumoides Shuey and Oenenathe javanica (Blume) DC. 'Flamingo', Phyla lanceolata (Michx.) Greene also had high P recovery rates. The potential exists for using SSF CWs to concomitantly produce aquatic garden plants and attenuate nutrients in a sustainable nursery enterprise.
\end{abstract}

\footnotetext{
Received for publication 5 Nov. 2007. Accepted for publication 6 Jan. 2008.

Support for this project by the Floriculture and Nursery Research Initiative for Environmental and Resource Management Practices and Strategies, USDA Agriculture Research Service, Ft. Pierce, $\mathrm{FL}$, is gratefully acknowledged.

Technical contribution no. 5386 of the Clemson University Experiment Station.

We thank Sarah White, Deidre Jones, and Robby Taylor for their invaluable assistance, and Carolina Nurseries Inc. and Fafard Inc. for their donations of plant material and soilless media.

Mention of a trademark, proprietary product, or vendor does not constitute a guarantee or warranty of the product by the authors and does not imply its approval to the exclusion of other products or vendors that also may be suitable.

${ }^{1}$ Extension Horticulturist.

${ }^{2}$ Director of Research.

${ }^{3}$ Assistant Professor.

${ }^{4}$ Professor.

${ }^{5}$ Professor and Chair.

${ }^{6}$ To whom reprint requests should be addressed; e-mailbplmsk@clemson.edu
}

Container production in nursery and greenhouse operations using soilless media involves inputs of fertilizers, growth regulators, insecticides, and fungicides. Repeated excessive irrigation leads to leaching and loss of nutrients and chemicals in runoff. The presence of nutrients in runoff and concerns of their impact on surface and groundwater quality has undergone increasing interest and scrutiny from the public, environmental groups, governmental agencies, and elected officials. Since its enactment, the U.S. Environmental Protection Agency (EPA) has enforced provisions of the Clean Water Act (1972) related to point-source pollution. In 1999, the EPA began enforcing nonpoint source pollution controls specified in section 303(d) of the Clean Water Act, which mandates that all states implement a Total Maximum Daily Load (TMDL) program for all watersheds and bodies of water (U.S. EPA, 2000). A TMDL is the maximum amount of pollutant that a water body can receive from point and nonpoint sources and still maintain its designated use and value (e.g., drinking water, fish and wildlife habitat, recreation, and so on). The Clean Water Act (U.S. EPA, 1994) lists nitrogen (N) and phosphorus (P) as potential pollutants of impaired water bodies. Offsite movement of nitrate-nitrogen $\left(\mathrm{NO}_{3}{ }^{-}\right)$and soluble reactive phosphate $\left(\mathrm{H}_{2} \mathrm{PO}_{4}^{-}, \mathrm{HPO}_{4}{ }^{2-}\right.$, and $\left.\mathrm{PO}_{4}{ }^{3-}\right)$ from nursery and greenhouse operations may lead to excessive algal and aquatic plant growth in surface waters, resulting in accelerated eutrophication. In general, freshwater systems are P-limited and more prone to $\mathrm{P}$ inputs, whereas $\mathrm{N}$ often limits primary production in estuarine and marine environments (Carpenter et al., 1998).

The maximum contaminant level for $\mathrm{NO}_{3}^{-}$in drinking water is $10 \mathrm{mg} \cdot \mathrm{L}^{-1}$ (National Academy of Sciences, 1977). No federal limits on $\mathrm{P}$ contamination in freshwater have been established as a result of variations in size, hydrology, and depth of rivers and lakes and regional differences in $P$ impacts. However, the U.S. EPA recommends that total $\mathrm{P}$ not exceed $0.05 \mathrm{mg} \cdot \mathrm{L}^{-1}$ in any streams discharging into lakes or reservoirs and $0.10 \mathrm{mg} \cdot \mathrm{L}^{-1}$ in streams or other flowing waters that do not (U.S. EPA, 1986).

Fertigation runoff in greenhouse crop production can contain $100 \mathrm{mg} \cdot \mathrm{L}^{-1} \mathrm{NO}_{3}-\mathrm{N}$ (Wood et al., 1999). In nursery crop production, nursery runoff $\mathrm{NO}_{3}-\mathrm{N}$ concentrations range from 0.1 to $135 \mathrm{mg} \cdot \mathrm{L}^{-1}$ (Alexander, 1993; Taylor et al., 2006; Yeager et al., 1993 ) and $\mathrm{P}$ levels from 0.01 to $20 \mathrm{mg} \cdot \mathrm{L}^{-1}$ (Alexander, 1993; Headley et al., 2001; James, 1995; Taylor et al., 2006). These cited $\mathrm{N}$ and $\mathrm{P}$ runoff ranges could be higher or lower in other nursery and greenhouse crop production systems.

Recently TMDLs of nutrients in agricultural runoff were adopted by environmental regulatory agencies in every state (Yeager, 2006). This follows a trend in which state governments have been passing more stringent laws and regulations assessing and regulating nonpoint sources of pollutants beyond the scope of the provisions of the Clean Water Act.

Constructed wetlands (CWs) have been promoted as an inexpensive, low-technology approach to comply with increasingly stringent environmental regulations regarding the discharge of nonpoint source pollutants in greenhouse and nursery production (Arnold et al., 1999; Berghage et al., 1999). Surfaceflow (SF) and subsurface flow (SSF) CWs are two commonly used wetland designs to treat agricultural wastewater (Berghage et al., 1999; Scholz and Lee, 2005). A SF $\mathrm{CW}$ resembles a shallow $(0.2$ to $0.8 \mathrm{~m})$ freshwater marsh and generally requires a large land area for wastewater treatment (Kadlec and Knight, 1996). To remediate nursery and greenhouse wastewater, surface area can be reduced with a concomitant increase in depth $(\approx 1.25$ to $1.5 \mathrm{~m})$, which promotes anaerobic conditions that facilitate denitrification. 
Alternatively, greenhouse and nursery operations constrained by limited production space and expensive land can use a SSF $\mathrm{CW}$, which consists of a lined or impermeable basin filled with a coarse medium, typically gravel, and wetland plants (Kadlec and Knight, 1996). Wastewater flows horizontally or vertically below the surface of the media to prevent exposure to humans or wildlife. SSF CWs can be operated in continuous-flow or batch-load treatment modes with varying hydraulic residence times (Burgoon et al., 1995).

Nitrogen removal from SSF CWs is accomplished primarily by denitrification and plant uptake (Vymazal, 2007). Inorganic or organic $\mathrm{P}$, which has no valency changes during its biotic assimilation or microbial decomposition, is mainly removed through microbial and plant uptake (Vymazal, 2007). Roots and rhizomes support rhizospheric microorganisms by providing colonizing sites exuding carbohydrates, sugars, amino acids, enzymes, and many other compounds (Rovira, 1969) and oxidizing the rhizosphere (Wießner et al., 2002), which fosters microbial activity.

One of the many factors that control the efficiency of nutrient and bacterial removal in wetlands is vegetation type (Guntenspergen et al., 1989). Wetland plants have speciesspecific efficiencies regarding their abilities to aerate water, grow within the constraints of the wetland environment, and remove nutrients and heavy metals (Maschinski et al., 1999). Previously studied aquatic emergent plants for $\mathrm{CWs}$ include reed canarygrass (Phalaris arundinacea L.), common reed [Phragmites australis (Cav.) Trin. Ex Steud.], reed mannagrass [Glyceria maxima (Hartman) Holmb.], softstem bulrush [Schoenoplectus tabernaemontani (C. C. Gmel.) Palla], yellow flag (Iris pseudacorus L.), and cattail (Typha spp. L.) (Ansola et al., 1995; Hunter et al., 2001; Wolverton et al., 1983). They have not been widely used because of their potential invasiveness. Additionally, their high rates of biomass production necessitate periodic harvesting to prevent the seasonal export of nutrients, particularly $P$, through vegetative decomposition (Hunter et al., 2001).
In this study, we investigated a costeffective approach suggested by Adler et al. (2003): "One way to reduce water treatment costs is to produce a product of value concomitant with treatment of the water." Instead of traditional wetland plants, commercially available aquatic garden plants can be used in a production/remediation system that could generate revenue. Few studies have examined the ability of aquatic garden plants to thrive in SSF CWs and recover nursery runoff rates of $\mathrm{N}$ and $\mathrm{P}$ (Arnold et al., 1999, 2003; Holt et. al, 1999).

In an earlier study, we investigated the potential of seven aquatic garden plants to assimilate $\mathrm{N}$ and $\mathrm{P}$ in a laboratory-scale, gravel-based SSF CW system (Polomski et al., 2007). Louisiana Iris hybrid 'Full Eclipse' exhibited the highest $\mathrm{N}$ recovery rate, whereas similar $\mathrm{P}$ recovery rates were observed in Canna $\times$ generalis Bailey (pro sp.) 'Bengal Tiger,' Canna $\times$ generalis Bailey (pro sp.) 'Yellow King Humbert,' Iris 'Full Eclipse,' Peltandra virginica (L.) Schott, and Pontederia cordata L. 'Singapore Pink' (Polomski et al., 2007). Our objective was to investigate five additional commercially available aquatic herbaceous emergent garden plants - three upright and two creeping - for their ability to thrive and recover $\mathrm{N}$ and $\mathrm{P}$ in a laboratory-scale wetland system that approximated a SSF CW.

\section{Materials and Methods}

Experimental procedures were similar to those described by Polomski et al. (2007); however, an abbreviated description follows with an emphasis on the experimental setup and nutrient solution treatments.

Plant culture. This greenhouse study was conducted from 2003 to 2004 in Clemson University's Biosystems Research Complex (lat $34^{\circ} 40^{\prime} 8^{\prime \prime} \mathrm{N}$, long. $82^{\circ} 50^{\prime} 40^{\prime \prime} \mathrm{W}$, Clemson, SC). Five herbaceous emergent aquatic plants were chosen for their aesthetic features and commercial availability (Table 1). Divisions of miniature cattail (Typha minima Hoppe), Rhyncospora colorata (L.) H. Pfeiffer, and Oenanthe javanica 'Flamingo' were separated from stock plants (Charleston
Aquatic Nursery, Johns Island, SC). Micropropagated plantlets of Thalia geniculata $\mathrm{f}$. rheumoides were purchased from a commercial tissue culture laboratory (Agri-Starts II, Apopka, FL). Phyla lanceolata (Charleston Aquatic Nursery) was rooted from 7.6- to $10.2-\mathrm{cm}$ long stem cuttings and then individual plants were transplanted into $15-\mathrm{cm}$ diameter containers containing a peat/vermiculite growing substrate (Fafard Germination Mix; Fafard, Anderson, SC). Plants were maintained on the greenhouse bench in water-filled plastic-lined trays and watered and fertilized as needed.

The laboratory subsurface treatment wetland was simulated by two polyethylene containers: a $16.5-\mathrm{cm}$ diameter "azalea" container filled with pea gravel and placed inside a $16.7-\mathrm{cm}$ diameter aquatic container (2.8-L container with no drainage holes) so their rims were even. An equilibrium isotherm experiment indicated no detectable $\mathrm{P}$ adsorption by the pea gravel (Polomski et al., 2007).

Two to 4 weeks before the start of an experiment, 40 to 50 plants of each species or cultivar were removed from their containers, their roots washed free of substrate, weighed, and transplanted into gravel-filled azalea containers. Single plantlets of Thalia geniculata f. rheumoides (Thalia), Oenanthe javanica 'Flamingo' (Oenanthe), and Phyla lanceolata (Phyla) and three each of Rhyncospora colorata (Rhyncospora) and Typha minima $(T y p h a)$ were planted in each container. After placing the azalea inside the aquatic container, $\approx 1.35 \mathrm{~L}$ of a $10 \%$ modified Hoagland's solution $\left(21.57 \mathrm{mg} \cdot \mathrm{L}^{-1} \mathrm{~N}\right.$ and 3.63 $\mathrm{mg} \cdot \mathrm{L}^{-1} \mathrm{P}$ ) (Hoagland and Arnon, 1950) was added until water appeared at the gravel surface. During acclimation, plants were watered every 2 or $3 \mathrm{~d}$ to maintain water levels just below the gravel surface.

Average daily temperatures, relative humidity, and daily light integral are listed in Table 2. A 16-h photoperiod was maintained during the winter months with $1000-\mathrm{W}$ metal halide lights.

Treatments. Five treatment levels of a modified Hoagland's solution ("Solution 1" using $\mathrm{NO}_{3}-\mathrm{N}$ ) contained the following mean concentrations of $\mathrm{N}$ and $\left.\mathrm{P}\left(\mathrm{mg} \cdot \mathrm{L}^{-1}\right): 1\right) 0.39 \mathrm{~N}$,

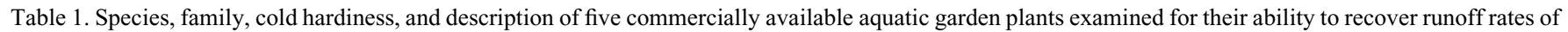
nitrogen and phosphorus. ${ }^{z}$

\begin{tabular}{|c|c|c|c|}
\hline$\overline{\text { Species }}$ & Family & USDA cold hardiness zone & Description \\
\hline $\begin{array}{l}\text { Oenenathe javanica } \\
\text { Flamingo }\end{array}$ & Apiaceae & $5-11$ & $\begin{array}{l}\text { Low-growing Korean native, rainbow water parsley has aromatic pink, } \\
\text { white, and green leaves with the aroma of parsley, and grows } \\
15 \mathrm{~cm} \text { high; white umbels emerge in summer through fall. }\end{array}$ \\
\hline Phyla lanceolata & Verbenaceae & $5-11$ & $\begin{array}{l}\text { Creeping North American native, lanceleaf frogfruit grows } 5-10 \mathrm{~cm} \\
\text { high, tolerates light foot traffic, and produces tiny white flowers that } \\
\text { fade to yellow and then pink; foliage turns reddish pink in fall. }\end{array}$ \\
\hline Rhyncospora colorata & Cyperaceae & $8-11$ & $\begin{array}{l}\text { Native to North America, white-top sedge grows } 30-61 \mathrm{~cm} \text { tall and } \\
\text { produces white starlike flowers. }\end{array}$ \\
\hline $\begin{array}{l}\text { Thalia geniculata } \\
\text { f. rheumoides }\end{array}$ & Marantaceae & $8-11$ & $\begin{array}{l}\text { Widely distributed in parts of the Americas and West Africa, } \\
\text { red-stemmed alligator flag has reddish purple petiole, sheath, and } \\
\text { pulvinus and bears long arching flower spikes of silvery-purple } \\
\text { flowers; grows } 0.6-3 \mathrm{~m} \text { tall and } 0.6--1.8 \mathrm{~m} \text { wide. }\end{array}$ \\
\hline Typha minima & Typhaceae & $3-9$ & $\begin{array}{l}\text { Native to parts of the Middle East and central Asia, miniature cattail } \\
\text { reaches a garden height of } 30-46 \mathrm{~cm} \text {; brown marble-sized catkins rise } \\
\text { above its } 3-6 \mathrm{~mm} \text { wide blue-green leaves. }\end{array}$ \\
\hline
\end{tabular}


Table 2. Experiment dates and selected environmental variables (mean $\pm \mathrm{SE}$ ) for the two replicates of each species conducted in the Biosystems Research Complex greenhouses, Clemson University, Clemson, SC.

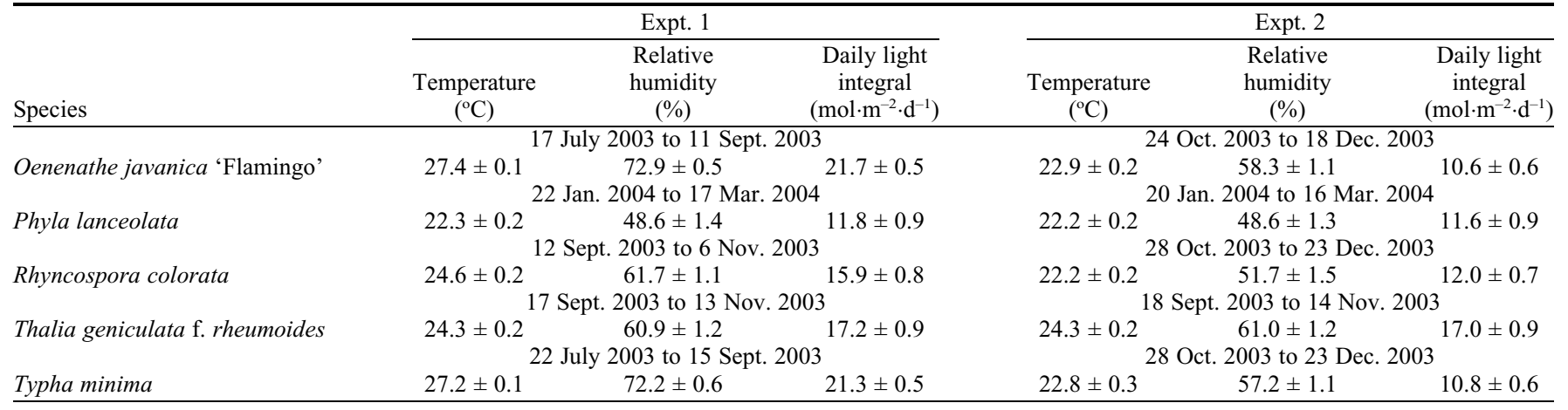

$0.07 \mathrm{P}$; 2) $1.75 \mathrm{~N}, 0.18 \mathrm{P}$; 3) $10.44,1.86 \mathrm{P}$; 4) $21.57 \mathrm{~N}, 3.63 \mathrm{P}$; and 5) $36.81 \mathrm{~N}, 6.77 \mathrm{P}$. These concentrations encompassed the typical range of nutrients found in constructed wetland discharge and nursery runoff and used in nursery irrigation. The initial $\mathrm{pH}$ of the nutrient solution was adjusted to 6.2 with $6 \mathrm{~N} \mathrm{H}_{2} \mathrm{SO}_{4}$.

At the start of the experiment, 30 acclimatized plants were removed from their aquatic containers, flushed with deionized water, and then returned to the aquatic containers that had been emptied and rinsed with deionized water. The appropriate treatment solution was batch-loaded into the containers with plants until it was visible at the gravel surface. Six containers without plants (gravel only) received 10.44 and $1.86 \mathrm{mg} \cdot \mathrm{L}^{-1} \mathrm{~N}$ and $\mathrm{P}$, respectively. Thereafter, nutrient solution was supplied every $2 \mathrm{~d}$ to maintain the water level at the gravel surface.

Containers were arranged in a randomized complete block design with six replicates. Experiments were repeated twice for each species during the time periods listed in Table 2.

Data collection. During the course of each experiment, the volume of nutrient solution supplied to each wetland unit was recorded over the 8 -week period. When the experiment was terminated, the above- and belowground portions of each plant were severed at the gravel surface and weighed. The belowground portions, which included roots that had grown through the drainage holes of the gravel-filled azalea containers, were placed over a screen and washed with tapwater, rinsed with distilled water, and then weighed. Dried roots and shoots ( $80{ }^{\circ} \mathrm{C}$ to constant dry weight) were ground separately in a Wiley Mill (Thomas Scientific, Swedesboro, NJ) to pass through a 40-mesh $(0.425-\mathrm{mm})$ screen. $\mathrm{N}$ and $\mathrm{P}$ tissue concentrations were determined as described by Polomski et al. (2007). To normalize differences in nutrient concentrations as a result of growth differences between treatments, $\mathrm{N}$ and $\mathrm{P}$ plant tissue nutrient content was calculated by multiplying plant part dry weight by nutrient concentration. Whole plant $\mathrm{N}$ and $\mathrm{P}$ content was derived by adding above- and belowground mineral content.
The water that remained in the aquatic containers was sampled and stored at $4{ }^{\circ} \mathrm{C}$ until anion analysis with a Dionex AS50 IC with AS50 autosampler (Dionex Corp., Sunnyvale, CA) to determine the percentage of recovered nutrient $[(\mathrm{mg} \mathrm{N}$ or $\mathrm{P}$ supplied $-\mathrm{mg}$ nutrient remaining in solution $\div$ mg $\mathrm{N}$ or $\mathrm{P}$ supplied) $\times 100]$.

Statistical analysis. Data from repetitions of the experiments were pooled because analysis of variance indicated no significant treatment interactions with replication and block. Regression analyses were performed for each species to describe changes in biomass and nutrient recovery relative to $\mathrm{N}$ or $\mathrm{P}$ supplied. The analysis indicated significant slope for biomass and nutrient uptake efficiency (i.e., the proportion of nutrient applied that is assimilated by the plant) for each species. Comparison of slopes among the species was accomplished using linear contrasts and $F$ tests. Differences between shoot and root concentration means and content means were determined by Student's $t$ tests. All analyses were performed with SAS (version 9.1 for Windows; SAS Institute, Cary, NC), and all tests were conducted with $\alpha=0.05$.

\section{Results and Discussion}

Biomass production. Growth rates increased linearly and were highly correlated with levels of $\mathrm{N}$ and $\mathrm{P}$ supplied (Fig. 1A-B). Thalia was supplied with greater amounts of $\mathrm{N}$ and $\mathrm{P}$ than the other species as a result of its higher evapotranspiration rate. Higher quantities of nutrients resulted in the highest rate of dry weight accumulation. Rhyncospora received the least amount of $\mathrm{N}$ and $\mathrm{P}$ over the 8-week period and had the lowest growth rate compared with Thalia, Phyla, and Oenanthe (Fig. 1A-B). Gravel-only containers receiving 10.44 and $1.86 \mathrm{mg} \cdot \mathrm{L}^{-1} \mathrm{~N}$ and $\mathrm{P}$, respectively, were supplied with $62 \%$ to $86 \%$ less $\mathrm{N}$ and $52 \%$ to $86 \%$ less $\mathrm{P}$ than planted containers receiving the same level of $\mathrm{N}$ and $\mathrm{P}$ (data not presented). Although Oenanthe and Phyla received nearly equal amounts of N and P, Phyla exhibited a higher growth rate than Oenanthe. When supplied with the two lowest treatment levels of $\mathrm{N}$ and $\mathrm{P}$, all species exhibited visual deficiency symptoms that included spindly growth and chlorotic, senescent older leaves. Symptoms were more pronounced in Thalia than in the other four species.

Nitrogen and phophorus recovery. Nitrogen and $\mathrm{P}$ recovery rates were determined by comparing the amount of $\mathrm{N}$ or $\mathrm{P}$ supplied and assimilated in whole plant tissues with an optimal recovery rate in which all $\mathrm{N}$ or $\mathrm{P}$ supplied was recovered in the tissues. Nitrogen and $\mathrm{P}$ content of whole plant tissues increased linearly and was highly correlated with the amount supplied to each species (Fig. 2A-B). Nitrogen recovery rate of Thalia and Oenanthe was similar to the optimal recovery rate of $\mathrm{N}$. Their $\mathrm{N}$ assimilation rates were higher than Phyla and Rhyncospora (Fig. 2A). Typha had the lowest N recovery rate (Fig. 2A) contrary to previous research on cattail species (Typha latifolia L., $T$. angustifolia L., T. orientalis L., and $T$. domingensis Pers.) in CWs (e.g., Scholz and Lee, 2005). Our N source may have affected uptake by Typha, because $\mathrm{NH}_{4}{ }^{+}$is the predominant form of inorganic $\mathrm{N}$ in acidic, waterlogged, wetland soils (Mitsch and Gosselink, 2007). However, Typha orientalis showed no preference for $\mathrm{N}$ source in a hydroponics study with four different $\mathrm{N}$ sources (Cary and Weerts, 1984). Typha latifolia produces optimal growth with either $\mathrm{NH}_{4}{ }^{+}$or $\mathrm{NO}_{3}{ }^{-}$at pH 5.0 to 7.0 (Brix et al., 2002). With $\mathrm{NH}_{4}^{+}, T$. latifolia has a higher relative growth rate, greater tissue concentration of major nutrients, greater content of adenine nucleotides, and a higher affinity for inorganic $\mathrm{N}$ uptake than with $\mathrm{NO}_{3}{ }^{-}$. Maximum uptake rate $\left(\mathrm{V}_{\max }\right)$ was highest for $\mathrm{NH}_{4}{ }^{+}$at $\mathrm{pH} 6.5$ and at $\mathrm{pH} 5.0$ for $\mathrm{NO}_{3}{ }^{-}$ (Brix et al., 2002).

None of the species had $\mathrm{P}$ assimilation rates that were similar to the optimal $P$ recovery rate (Fig. 2B). Thalia received more $\mathrm{P}$ than the other species and had the highest $\mathrm{P}$ recovery rate followed by Oenanthe and Phyla. Rhyncospora had the lowest $\mathrm{P}$ recovery/assimilation rate compared with Thalia, Oenanthe, and Phyla (Fig. 2B).

Compared with a similar study with seven other aquatic garden species (Polomski et al., 2007), Thalia, Rhyncospora, and Oenanthe had $\mathrm{N}$ recovery rates similar to Louisiana iris 'Full Eclipse' and Pontederia 

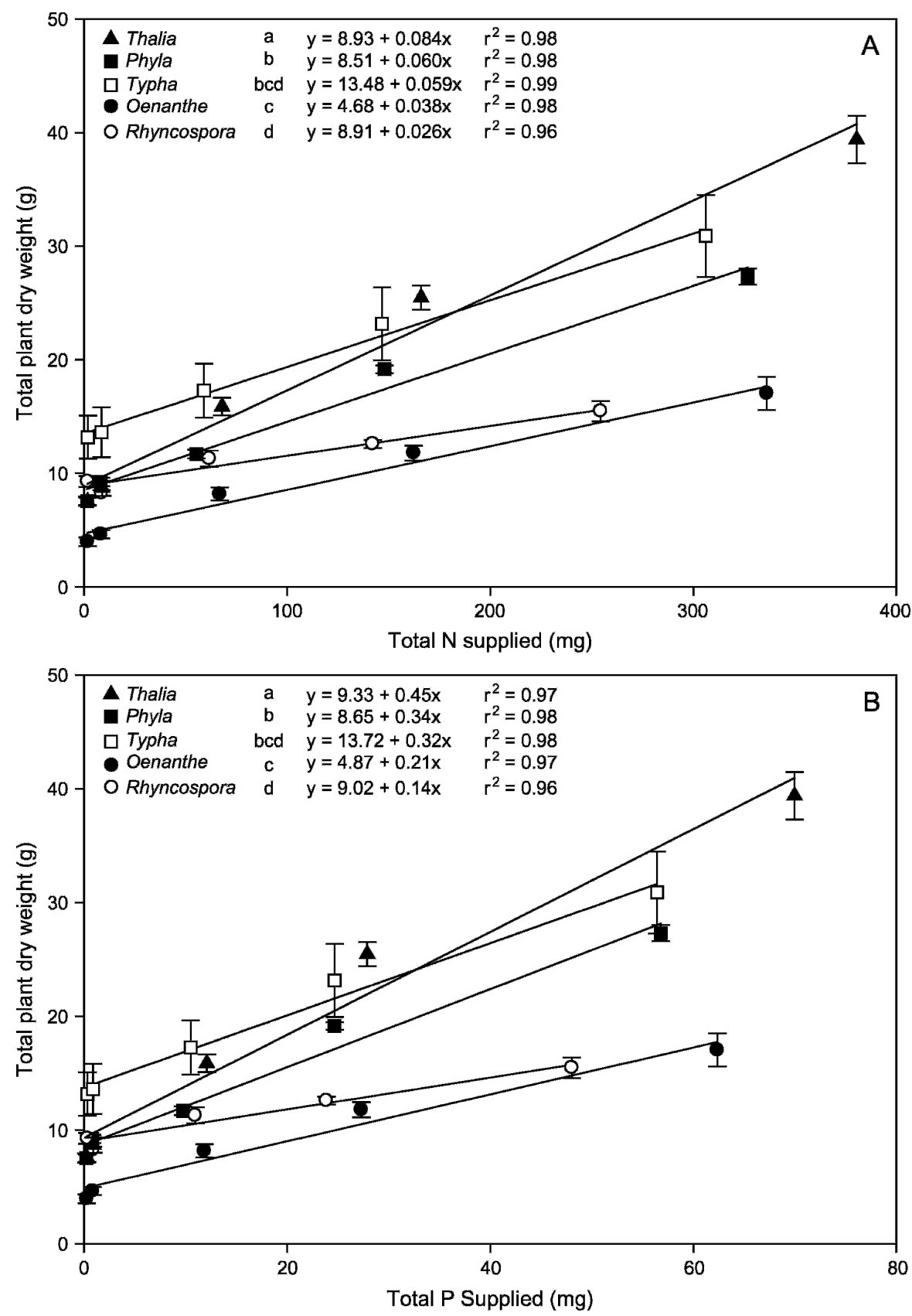

Fig. 1. The effect of (A) nitrogen $(\mathrm{N})$ and $(\mathbf{B})$ phosphorus $(\mathrm{P})$ on whole plant dry weight of five greenhousegrown containerized aquatic garden plants over an 8 -week period. Five concentrations of modified Hoagland's solution (mg. $\left.\mathrm{L}^{-1}\right)$ : 1) $0.39 \mathrm{~N}, 0.07 \mathrm{P}$; 2) $1.75 \mathrm{~N}, 0.18 \mathrm{P}$; 3) $10.44,1.86 \mathrm{P}$; 4) $21.57 \mathrm{~N}, 3.63 \mathrm{P}$; and 5) $36.81 \mathrm{~N}, 6.77 \mathrm{P}$ were initially batch-loaded and then supplied every $2 \mathrm{~d}$ to maintain the water level at the gravel surface. Vertical bars $= \pm$ SE. Data points are the means of 12 plants. Slopes of the regression lines were compared using linear contrasts and $F$ tests; species with different letters have significantly different slopes $(P \leq 0.05)$.

cordata 'Singapore Pink'. $\mathrm{P}$ recovery rates of Thalia were similar to Canna $\times$ generalis 'Bengal Tiger', Peltandra virginica, and Pontederia cordata 'Singapore Pink'.

There were no differences between species or treatment levels in the concentration of $\mathrm{N}$ and $\mathrm{P}$ remaining in the containers at harvest. Less than $4 \%$ and $7 \%$ of the original amount of $\mathrm{N}$ and $\mathrm{P}$ supplied to the plants, respectively, was detected in the remaining solution (data not shown). Of the original amount of $\mathrm{N}$ and $\mathrm{P}$ supplied to gravel-only containers, $37 \%$ to $53 \% \mathrm{~N}$ and $27 \%$ to $54 \%$
$\mathrm{P}$ remained (data not shown). These findings were consistent with other studies that showed an improvement in nutrient removal when plants were present in SSF wetlands (Huett et al., 2005; Jing et al., 2002).

Depletion of $\mathrm{P}$ in the gravel-only containers could have resulted from assimilation by the thin film of algae present near the gravel surface and from biofilm-single cells or pools of microorganisms embedded in a matrix of microbial-derived polymers attached to the gravel substrate (Zhang and Bishop, 1994). Phosphorus precipitation was highly unlikely because the $\mathrm{pH}$ was not alkaline enough (mean $\mathrm{pH}, 7.1$ ). Nitrogen depletion may have occurred through denitrification processes.

Nitrogen and phosphorus concentration. To characterize differences in $\mathrm{N}$ and $\mathrm{P}$ tissue accumulation among species, we reported concentration of tissue nutrients in accordance with typical wetland plant nutrient uptake and mass balance studies. Nitrogen concentration in roots exceeded the amount in shoots at every level of $\mathrm{N}$ supplied for Phyla (Table 3). A similar trend was observed with Oenanthe at concentrations 21.57 $\mathrm{mg} \cdot \mathrm{L}^{-1} \mathrm{~N}$ or less. However, at the highest treatment level, $\mathrm{N}$ concentration was comparable between roots and shoots (Table 3 ). Similar results were reported for Oenanthe javanica receiving $16.8 \mathrm{mg} \cdot \mathrm{L}^{-1}$ and 33.6 $\mathrm{mg} \cdot \mathrm{L}^{-1} \mathrm{~N}$ in sand culture (Wang et al., 2002) and Oenanthe sarmentosa sampled from agricultural drainage waterways in central California (Rejmankova, 1992). Similar to Oenanthe sarmentosa, more biomass was allocated in $O$. javanica to the aboveground than belowground plant parts with increasing levels of nutrients (data not presented). This preferential allocation of nutrients to belowground parts rather than aboveground parts in response to reduced nutrient status commonly occurs in plants growing in infertile habitats (Chapin, 1980).

Typha and Thalia had higher $\mathrm{N}$ concentration in the shoots than the roots at levels 0.39 or greater and $1.75 \mathrm{mg} \cdot \mathrm{L}^{-1}$ or greater $\mathrm{N}$, respectively, similar to the trend exhibited by Canna $\times$ generalis 'Yellow King Humbert', Colocasia esculenta (L.) Schott var. antiquorum (Schott) Hubbard \& Rehd. 'Illustris', and Peltandra virginica (Polomski et al., 2007). Phosphorus concentration in Thalia and Phyla was highest in shoots at every treatment level, whereas the highest $\mathrm{P}$ concentration in Typha was in roots at every treatment level.

Contrary to Typha minima, $\mathrm{N}$ concentration of T. angustifolia roots and rhizomes (Steinbachova-Vojtiskova et al., 2006) and T. latifolia rhizomes (Cizkova-Koncalova et al., 1996) increases with increasing nutrient availability in contrast to shoots. T. minima shoot $\mathrm{N}$ concentration was similar to $T$. angustifolia shoot $\mathrm{N}$ at comparable $\mathrm{N}$ treatment levels (Steinbachova-Vojtiskova et al., 2006); however, root and rhizome $\mathrm{N}$ concentration of $T$. angustifolia exceeded the concentration of Typha minima. This discrepancy could be explained by the diminutive size of $T$. minima and the propensity of $T$. angustifolia to allocate resources to belowground structures, which contributes to its ability to thrive and compete in eutrophic habitats (Steinbachova-Vojtiskova et al., 2006). T. angustifolia shoot dry weight increases and root dry weight decreases with increasing nutrient availability (Steinbachova-Vojtiskova et al., 2006), similar to T. minima (data not presented).

In natural stands of Typha latifolia from Aiken, SC (Boyd, 1978), whole plant N and $\mathrm{P}$ concentrations were 1.7 - and 2.3-fold 

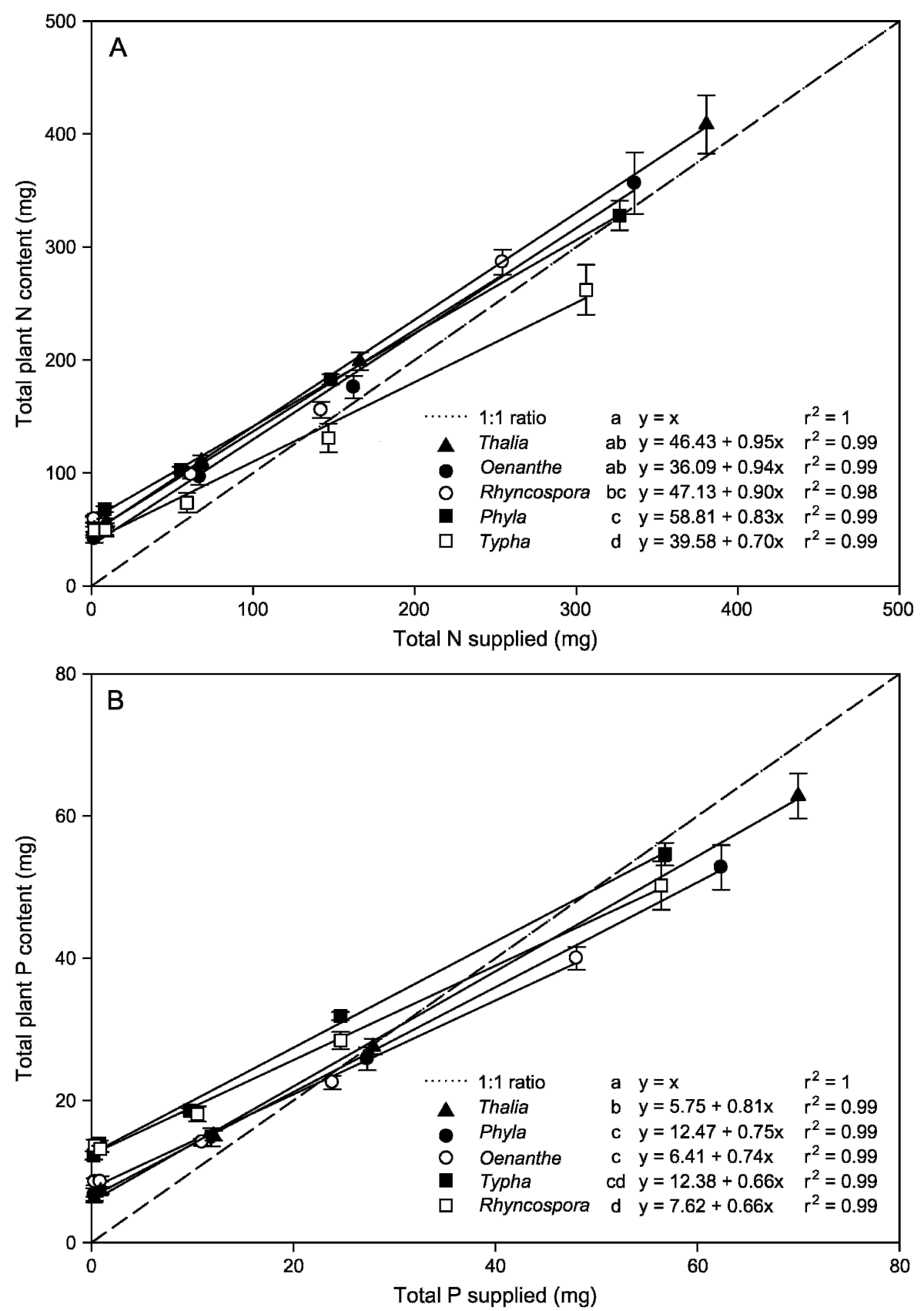

Fig. 2. (A) Nitrogen (N) and (B) phosphorus (P) recovered in whole plant tissues of five greenhouse-grown aquatic garden species over an 8 -week period. Five concentrations of modified Hoagland's solution (mg. $\mathrm{L}^{-1}$ ): 1) $0.39 \mathrm{~N}, 0.07 \mathrm{P}$; 2) $1.75 \mathrm{~N}, 0.18 \mathrm{P}$; 3) $10.44 \mathrm{~N}, 1.86 \mathrm{P}$; 4) $21.57 \mathrm{~N}, 3.63 \mathrm{P}$; and 5) $36.81 \mathrm{~N}$, 6.77 P were initially batch-loaded and then supplied every $2 \mathrm{~d}$ to maintain the water level at the gravel surface. Vertical bars $= \pm \mathrm{SE}$. Data points are the means of 12 plants. The dashed line represents an ideal $100 \%$ recovery rate. Slopes of the regression lines were compared using linear contrasts and $F$ tests; species with different letters have significantly different slopes $(P \leq 0.05)$.

less, respectively, than those of Typha minima receiving the lowest treatment level in our study. Boyd (1978) expected these concentrations to be 1.5 to two times higher if $T$. latifolia received nutrient-rich effluent.

Breen (1990) evaluated Typha orientalis in an experimental wetland system in Australia comprised of $10-\mathrm{L}$ polyethylene buckets with gravel (3 to $7 \mathrm{~mm}$ diameter). Mean influent nutrient concentration was $31.83 \mathrm{mg} \cdot \mathrm{L}^{-1}$ total $\mathrm{N}$ and $11.47 \mathrm{mg} \cdot \mathrm{L}^{-1} \mathrm{P}$ during the 50-d experiment. Above- and belowground tissue $\mathrm{N}$ values of Typha similar to T. minima at our highest treatment level.

Rhyncospora shoots had a higher $\mathrm{N}$ concentration than roots at nutrient levels 10.4 $\mathrm{mg} \cdot \mathrm{L}^{-1} \mathrm{~N}$ or less, but $\mathrm{N}$ root concentration exceeded $\mathrm{N}$ shoot concentration at $36.8 \mathrm{mg} \cdot \mathrm{L}^{-1}$ $\mathrm{N}$. There were no differences in $\mathrm{P}$ between the shoots and roots of Rhyncospora at any treatment level. No trend was observed with Oenanthe. However, our P concentrations in Oenanthe shoots were within the range reported by Wang et al. (2002).

Nitrogen and phosphorus content. Nitrogen content of Oenanthe, Phyla, Rhyncospora, and Thalia shoots was greater tan $61 \%$ higher than roots at every $\mathrm{N}$ treatment level (Table 3). Similar sink strength of shoots was reported for Louisiana iris 'Full Eclipse' and Pontederia cordata 'Singapore Pink' (Polomski et al., 2007).

Typha roots were a dominant $\mathrm{N}$ sink at $0.39 \mathrm{mg} \cdot \mathrm{L}^{-1} \mathrm{~N}$ treatment level, containing $57 \%$ more $\mathrm{N}$ in roots than shoots; however, at the two highest treatment levels, shoots stored $59 \%$ and $69 \%$ more $\mathrm{N}$, respectively, than roots. A similar change in sink strength with increasing levels of $\mathrm{N}$ was observed with two cultivars of Canna $\times$ generalis and Colocasia esculenta var. antiquorum 'Illustris' (Polomski et al., 2007).

Phosphorus content of Oenanthe, Phyla, and Thalia was greater in shoots than roots at every treatment level. Oenanthe and Phyla shoot $\mathrm{P}$ exceeded $86 \%$ in shoots at treatment levels $1.86 \mathrm{mg} \cdot \mathrm{L}^{-1} \mathrm{P}$ or greater, similar to Louisiana iris 'Full Eclipse' (Polomski et al., 2007). Thalia shoots contained between $65 \%$ and $69 \%$ more $\mathrm{P}$ compared with roots at every treatment level, similar to Pontederia cordata 'Singapore Pink'. P concentration and content followed identical trends in Thalia and Phyla at each treatment level, similar to Pontederia 'Singapore Pink' (Polomski et al., 2007). In contrast, Typha $\mathrm{P}$ root content followed a similar trend to $\mathrm{P}$ root concentration; $\mathrm{P}$ root content was $57 \%$ to $61 \%$ greater than shoot $\mathrm{P}$ at every treatment level.

There were no statistical differences between Rhyncospora shoot and root P content at the two lowest treatment levels, but shoot $\mathrm{P}$ exceeded root $\mathrm{P}$ at treatment levels 1.86 $\mathrm{mg} \cdot \mathrm{L}^{-1} \mathrm{P}$ or greater. This partitioning of $\mathrm{P}$ to shoots instead of roots with increasing levels of $\mathrm{P}$ was also observed in Canna $\times$ generalis 'Bengal Tiger' and Colocasia esculenta var. antiquorum 'Illustris' (Polomski et al., 2007).

Taxa that preferentially allocate nutrients to aboveground biomass allow for the harvesting and removal of topgrowth. Continuous and long-term removal of excess $\mathrm{P}$ from CWs can be ensured by regularly harvesting pollution-tolerant species (Jing et al., 2001). In nursery/greenhouse production systems, container-grown aquatic garden plants receiving runoff channeled into nutrient attenuation/production $\mathrm{CW}$ beds can also be "harvested" to remove nutrients from the system. Removal of entire plants avoids $\mathrm{P}$ export to outflow and downstream environments from senescent, decomposing tissues 
Table 3. Nitrogen $(\mathrm{N})$ and phosphorus $(\mathrm{P})$ concentration and content of shoots and roots of five aquatic garden plants grown for 8 weeks in a laboratory scale wetland and receiving five treatment levels of $\mathrm{N}$ or $\mathrm{P}$ from a modified Hoagland's nutrient solution. ${ }^{\mathrm{z}}$

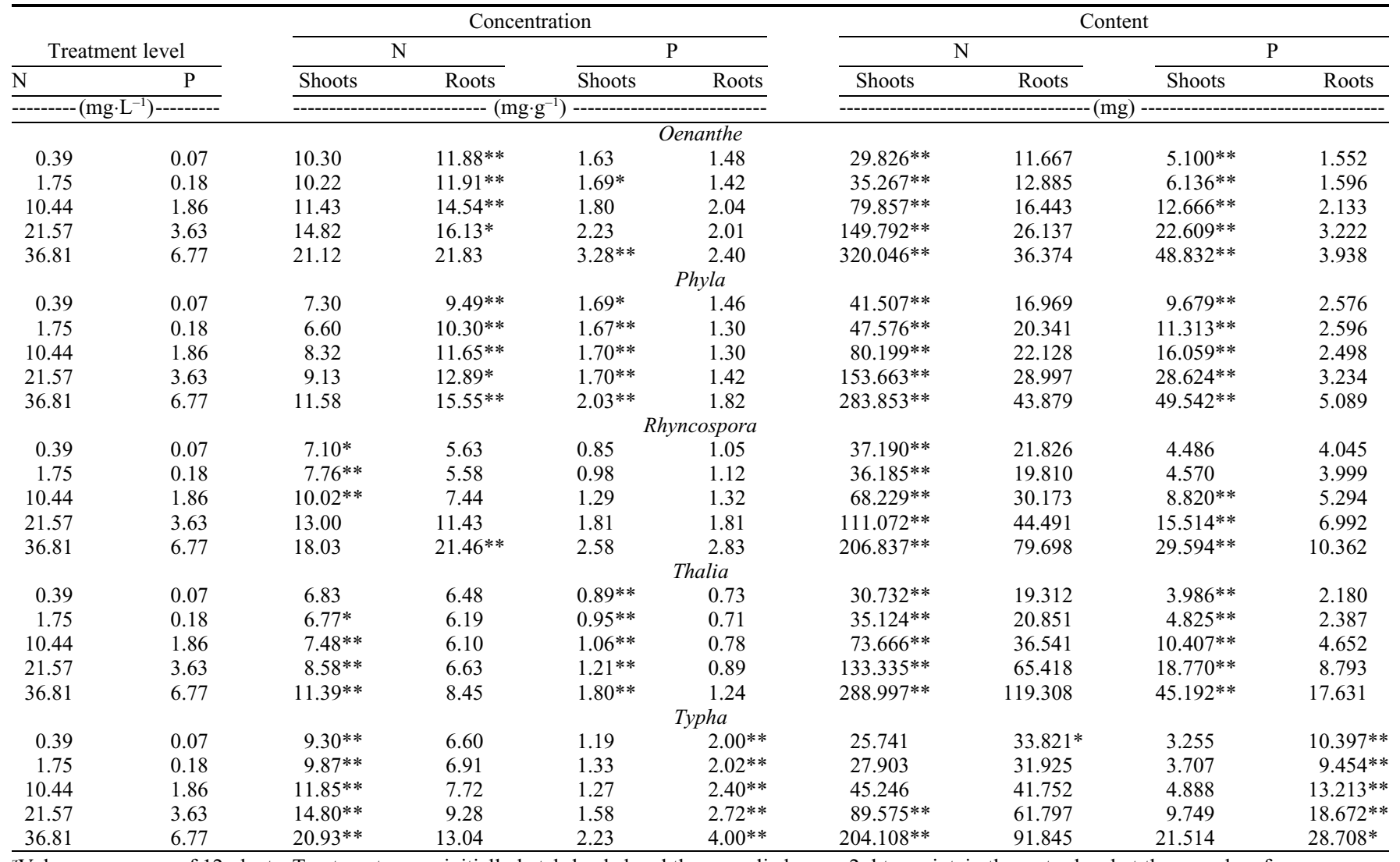

${ }^{\mathrm{z}}$ Values are means of 12 plants. Treatments were initially batch-loaded and then supplied every $2 \mathrm{~d}$ to maintain the water level at the gravel surface.

*, ** Mean separation by $t$ test comparing $\mathrm{N}$ and $\mathrm{P}$ in shoots and roots within species at each treatment level with significant differences at $P \leq 0.05$ and $P \leq 0.01$, respectively.

(Hunter et al., 2001). Plants with highly efficient $\mathrm{N}$ and $\mathrm{P}$ recovery rates such as Thalia and Oenanthe can be placed at the discharge end of a CW to "polish" the effluent. Also, they can be located at the inflow end of CWs because of their ability to assimilate high $\mathrm{N}$ and $\mathrm{P}$ concentrations. Thalia, Oenanthe, and Phyla may also be suited for SSF CWs in greenhouse production systems because of their ability to assimilate high volumes of nutrient-rich water, which reduces the amount of effluent that must be discarded.

The commercial value of aquatic garden plants offsets their production costs, which offers producers a sustainable, cost-effective, and low-maintenance remediation solution compared with conventional wastewater treatment technologies. Their usefulness could be expanded to other phytoremediation applications depending on the outcome of additional research assessing their ability to assimilate pesticides (e.g., Fernandez et al., 1999) and other anthropogenic pollutants (i.e., hydrocarbons and metals) (e.g., Fritioff and Greger, 2003). The aesthetic features of aquatic garden plants create markets and opportunities in commercial and residential landscape applications such as infiltration trenches (i.e., basins and rain gardens), retention ponds, and wet or dry detention basins.

Direct comparison of $\mathrm{N}$ and $\mathrm{P}$ recovery by the aquatic garden plants in this study with other investigations is precluded by differing hydraulic characteristics such as retention time, water level depth, and wastewater loading along with differences in species compositions and densities, media, and design and size of the systems. Nevertheless, the results support the use of aquatic garden plants as aesthetic and economically viable alternatives to traditional, obligate wetland plants in CWs and the need for further investigation to optimize species selection, cycling time, and production system design.

\section{Literature Cited}

Adler, P.R., S.T. Summeerfelt, D.M. Glenn, and F. Takeda. 2003. Mechanistic approach to phytoremediation of water. Ecol. Eng. 20:251264.

Alexander, S.V. 1993. Pollution control and prevention at containerized nursery operations. Water Sci. Technol. 28:509-517.

Ansola, G., C. Fernandez, and E. de Luis. 1995. Removal of organic matter and nutrients from urban wastewater by using an experimental emergent aquatic macrophyte system. Ecol. Eng. 5:13-19.

Arnold, M.A., B.J. Lesikar, A.L. Kenimer, and D.C. Wilkerson. 1999. Spring recovery of constructed wetland plants affects nutrient removal from nursery runoff. J. Environ. Hort. 17:5-10.

Arnold, M.A., B.J. Lesikar, G.V. McDonald, D.L. Bryan, and A. Gross. 2003. Irrigating landscape bedding plants and cut flowers with recycled nursery runoff and constructed wetland treated water. J. Environ. Hort. 21:89-98.

Berghage, R.D., E.P. MacNeal, E.F. Wheeler, and W.H. Zachritz. 1999. Green water treatment for the green industries: opportunities for biofiltration of greenhouse and nursery irrigation water and runoff with constructed wetlands. HortScience. 34:50-54.

Boyd, C.E. 1978. Chemical composition of wetland plants, p. 155-167. In: Good, R.E., D.F. Whigham, and R.L. Simpson (eds.). Freshwater wetlands: Ecological processes and management potential. Academic Press, New York, NY.

Breen, P.F. 1990. A mass balance method for assessing the potential of artificial wetlands for wastewater treatment. Water Res. 24:689697.

Brix, H., K. Dyhr-Jensen, and B. Lorenzen. 2002. Root-zone acidity and nitrogen source affects Typha latifolia $\mathrm{L}$. growth and uptake kinetics of ammonium and nitrate. J. Expt. Bot. 53:24412450.

Burgoon, P.S., K.R. Reddy, and T.A. DeBusk. 1995. Performance of subsurface-flow wetlands with batch-load and continuous-flow conditions. Water Environ. Res. 67:855862.

Carpenter, S.R., N.F. Caraco, D.L. Correll, R.W Howarth, A.N. Sharpley, and V.H. Smith. 1998. Nonpoint source pollution of surface waters with phosphorus and nitrogen. Ecol. Appl. 8:559-568.

Cary, P.R. and P.G.J. Weerts. 1984. Growth and nutrient composition of Typha orientalis as affected by water temperatures and nitrogen 
and phosphorus supply. Aquat. Bot. 19:105118.

Chapin, F.S., III. 1980. The mineral nutrition of wild plants. Ann. Rev. Ecol. Syst. 11:233-260.

Cizkova-Koncalova, H., J. Kvet, and J. Lukavska. 1996. Response of Phragmites australis, Glyceria maxima, and Typha latifolia to additions of piggery sewage in a flooded sand culture. Wetlands Ecol. and Mgt. 4:43-50.

eFloras.org. 2007. 1 Nov 2007. <http://www.efloras. org/index.aspx $>$.

Fernandez, R.T., T. Whitwell, M.B. Riley, and C.R. Bernard. 1999. Evaluating semiaquatic herbaceous perennials for use in herbicide phytoremediation. J. Amer. Soc. Hort. Sci. 124:539-544.

Fritioff, A. and M. Greger. 2003. Aquatic and terrestrial plant species with potential to remove heavy metals from stormwater. Int. J. Phytoremed. 5:211-224.

Guntenspergen, G.R., F. Stearns, and J.A. Kadlec. 1989. Wetland vegetation, p. 73-88. In: Hammer, D.A. (ed.). Constructed wetlands for wastewater treatment. Lewis Pub., Chelsea, MI.

Headley, T.R., D.O. Huett, and L. Davison. 2001. The removal of nutrients from plant nursery irrigation runoff in subsurface horizontal-flow wetlands. Water Sci. Technol. 44:77-84.

Hoagland, D.R. and D.I. Arnon. 1950. The waterculture method for growing plants without soil. Calif. Agr. Exp. Sta. Circ. 347.

Holt, T.C., B.K. Maynard, and W.A. Johnson. 1999. Nutrient removal by five ornamental wetland plant species grown in treatmentproduction wetland biofilters. HortScience 34: 521 (abstr.).

Huett, D.O., S.G. Morris, G. Smith, and N. Hunt. 2005. Nitrogen and phosphorus removal from plant nursery runoff in vegetated and unvegetated subsurface-flow wetlands. Water Res. 39:3259-3272.

Hunter, R.G., D.L. Combs, and D.B. George. 2001. Nitrogen, phosphorus, and organic carbon removal in simulated wetland treatment systems. Arch. Environ. Contam. Toxicol. 41:274-281.

James, E.A. 1995. Water quality of stored and runoff water in plant nurseries and implications for recycling. Combined Proc. Int. Plant Propagators' Soc. 45:117-120.
Jing, S.-R., Y.-F. Lin, D.-Y. Lee, and T.-W. Wang. 2001. Nutrient removal from polluted river water by using constructed wetlands. Bioresour. Technol. 76:131-135.

Jing, S.-R., Y.-F. Lin, T.-W. Wang, and D.-Y. Lee. 2002. Microcosm wetlands for wastewater treatment with different hydraulic loading rates and macrophytes. J. Environ. Qual. 31:690696.

Kadlec, R.H. and R.L. Knight. 1996. Treatment wetlands. CRC Press, Boca Raton, FL.

Maschinski, J., G. Southam, J. Hines, and S. Strohmeyer. 1999. Efficiency of a subsurface constructed wetland system using native southwestern U.S. plants. J. Environ. Qual. 28:225231.

Mitsch, W.J. and J.G. Gosselink. 2007. Wetlands. 4 th ed. Wiley, Hoboken, NJ.

National Academy of Sciences. 1977. Drinking water and health. National Research Council, Assembly of Life Sciences, Washington, DC.

Polomski, R.F., M.D. Taylor, D.G. Bielenberg, W.C. Bridges, S.J. Klaine, and T. Whitwell. 2007. Nutrient recovery by seven aquatic garden plants in a laboratory-scale subsurface constructed wetland. HortScience 42:1674 1680.

Rejmankova, E. 1992. Ecology of creeping macrophytes with special reference to Ludwigia peploides (H.B.K.). Raven. Aquatic Bot. 43:283-299.

Rovira, A.D. 1969. Plant root exudates. Bot. Rev. 35:35-57.

Scholz, M. and B. Lee. 2005. Constructed wetlands: A review. Int. J. Environ. Stud. 62:421-447.

Speichert, G. and S. Speichert. 2004. Encyclopedia of water garden plants. Timber Press, Portland, OR.

Steinbachova-Vojtiskova, L., E. Tylova, A. Soukup, H. Novicka, O. Votrubova, H. Lipavska, and H. Cizkova. 2006. Influence of nutrient supply on growth, carbohydrate, and nitrogen metabolic relations in Typha angustifolia. Environ. Exp. Bot. 57:246-257.

Taylor, M.D., S.A. White, S.L. Chandler, S.J. Klaine, and T. Whitwell. 2006. Nutrient management of nursery runoff water using constructed wetland systems. HortTechnology 16:610-614.
USDA, NRCS. 2007. The PLANTS database. National Plant Data Center, Baton Rouge, LA. 1 Nov 2007. <http://plants.usda.gov>.

U.S. Environmental Protection Agency (EPA). 1986. Quality criteria for water. EPA 440/586-001. Office of Water Regulations and Standards. Washington, DC. 21 Dec 2007. $<$ http://www.epa.gov/waterscience/criteria/ goldbook.pdf>.

U.S. EPA. 1994. Water quality standards handbook. 2nd ed. EPA 823-B94-005, Washington, DC. 21 Dec 2007. <http://www.epa.gov/water science/library/wqstandards/handbook.pdf>

U.S. EPA. 2000. The total maximum daily load (TMDL) program. EPA 841-F-00-009. Office of Water Regulations and Standards. Washington, DC. 21 Dec 2007. <http://www.epa.gov/ owow/tmdl/overviewfs.html $>$.

Vymazal, J. 2007. Removal of nutrients in various types of constructed wetlands. Sci. Total Environ. 380:48-65.

Wang, Q., Y. Cui, and Y. Dong. 2002. Phytoremediation of polluted waters: Potentials and prospects of wetland plants. Acta Biotechnol. 22:199-208

Wießner, A., P. Kuschk, M. Kastner, and U. Stottmeister. 2002. Abilities of helophyte species to release oxygen into rhizospheres with varying redox conditions in laboratory-scale hydroponic systems. Intl. J. Phytoremed. 4:115.

Wolverton, B.C., R.C. McDonald, and W.R. Duffer. 1983. Microorganisms and higher plants for wastewater treatment. J. Environ. Qual. 12:236-242.

Wood, S.L., E.F. Wheeler, R.D. Berghage, and R.E. Graves. 1999. Temperature effects on wastewater nitrate removal in laboratory-scale constructed wetlands. Amer. Soc. Agr. Eng. 42:185-190.

Yeager, T.H. 2006. The BMP consensus challenge. HortTechnology 16:386-389.

Yeager, T.H., R. Wright, D. Fare, C. Gilliam, J. Johnson, T. Bilderback, and R. Zondag. 1993. Six state survey of container nursery nitrate nitrogen runoff. J. Environ. Hort. 11:206208.

Zhang, T.C. and P.L. Bishop. 1994. Structure, activity and composition of biofilms. Water Sci. Technol. 29:335-344. 